\title{
Efektivitas Implementasi Program Inovasi Kelurahan di Kota Pontianak
}

\section{The Effectiveness of Kelurahan Innovation Program Implementation in Pontianak City}

\author{
Sri Maryuni \\ Universitas Tanjung Pura
}

\begin{abstract}
Abstrak
Program Inovasi Kelurahan merupakan salah satu usaha Pemerintah Kota Pontianak untuk membangun kapasitas dan memberdayakan kelurahan sebagai ujung tombak pelayanan kepada masyarakat melalui kolaborasi, koordinasi dan konsultasi yang intensif dengan Satuan Kerja Perangkat Daerah tertentu sebagai partner kerjanya. Efektifitas implementasi Program Inovasi Kelurahan di Kota Pontianak dapat dinilai dari empat 'tepat', yaitu: tepat kebijakannya, tepat pelaksananya, tepat target atau sasarannya dan tepat lingkungannya. Selain itu perlu didukung oleh tiga jenis dukungan, yaitu: dukungan politik, dukungan strategik dan dukungan teknis. Kegiatan-kegiatan yang ada dalam Program Inovasi Kelurahan di Kota Pontianak dinilai sudah efektif, karena sebagian besar kegiatan telah memobilisasi sumber daya yang ada di lingkungannya guna meningkatkan kapasitas dan memberdayakan kelurahan. Implementor atau pelaksana Program Inovasi Kelurahan di masing masing kelurahan telah sesuai antara tema kegiatannya dengan Satuan Kerja Perangkat daerah (SKPD) selaku Pembina kegiatan tersebut.Sedangkan kelompok sasaran yang terlibat dalam implementasi PIK adalah: institusi kelurahan, SKPD di lingkungan Pemerintah Kota Pontianak dan kelembagaan masyarakat di Kota Pontianak. Kegiatan-kegiatan yang ada di masing-masing kelurahan dalam Program Inovasi Kelurahan di Kota Pontianak dinilai sudah sesuai dengan lingkungannya, karena kegiatannya disesuaikan dengan kondisi lingkungannya dan telah memberikan manfaat yang luas kepada masyarakat. Disarankan Program Inovasi Kelurahan di Kota Pontianak berkesinambungan dari tahun ke tahun, karena program ini dapat mendorong kemandirian masyarakat dan institusi kelurahan untuk memperbaiki lingkungannya.
\end{abstract}

\section{Kata Kunci : Efektivitas, Program, Inovasi}

\begin{abstract}
Kelurahan Innovation Program (thereafter called PIK) is one of Pontianak Government's attempt of building capacity and empowering the kelurahan as the starting point of service to the community through intensive collaboration, coordination, and consultation with Certain Local Apparatus Work Unit as its work partner. The effectiveness of Kelurahan Innovation Program implementation in Pontianak City can be assessed from four "appropriateness": appropriate policy, appropriate implementation, appropriate target or goal and appropriate environment. In addition, it should be supported with three factors: politics, strategy, and technique. The activities existing in Kelurahan Innovation Program in Pontianak city has been
\end{abstract}


considered as effective, as most activities has mobilized the existing resource in its environment in order to improve the capacity and to empower the kelurahan. The implementer of Kelurahan Innovation Program in each kelurahan has been consistent with its activity theme, with Local Apparatus Work Unit (SKPD) as the Builder of activity. Meanwhile, the targeted groups involved in the implementation of PIK were: kelurahan institution, SKPD in Pontianak City government environment, and society institution in Pontianak City. The activities existing in each of kelurahan in Kelurahan Innovation Program in Pontianak City has been considered as consistent with its environment, as it has been adjusted with the environment condition and has benefited the public widely. The Kelurahan Innovation Program in Pontianak City is recommended to be conducted continuously over years, as this program can encourage the community independency and kelurahan institution to improve its environment.

Keywords: Effectiveness, Program, Innovation

\section{Pendahuluan}

Upaya memberantas kemiskinan menjadi tidak berarti, apabila program-program yang direncanakan oleh pemerintah atas dasar persepsi dan asumsi yang keliru terhadap sebab-sebab munculnya kemiskinan, dan perencanaan program anti kemiskinan dilakukan seragam baik dari segi bentuk dan model pelaksanaannya, tanpa memperhatikan adanya variasi dari berbagai definisi dan sebab terjadinya kemiskinan, serta lemahnya monitoring dari pemerintah terhadap program anti kemiskinan. Hal ini akan berakibat terjadinya penyimpangan baik dari segi seleksi penerimaan program maupun biaya yang digunakan untuk melaksanakan program, dan kurangnya dukungan penelitian perihal masalah-masalah kemiskinan serta evaluasi tentang dampak dari program-program anti kemiskinan terhadap perbaikan hidup orang miskin.

Kenyataan tersebut menunjukkan bahwa program penanggulangan kemiskinan yang telah dilakukan oleh pemerintah selama ini belum dapat mengatasi kemiskinan yang dialami oleh masyarakat. Hal ini membuat pemerintah mencoba merekayasa kembali bentuk program penanggulangan kemiskinan dengan menggabungkan Program Pengembangan Kecamatan dan program pengurangan kemiskinan ke dalam Program Inovasi Kelurahan. Program ini bersifat open menu, jenis kegiatan ini ditentukan sendiri oleh masyarakat sehingga akan menjawab kebutuhan yang spesifik dalam penanggulangan kemiskinan.

Keberadaan Program Inovasi Kelurahan memberikan arti dalam upaya meningkatkan partisipasi, swadaya serta berdayanya masyarakat dalam proses penanggulangan kemiskinan ataupun pembangunan di bidang perekonomian. Hal ini yang mendasari minat penulis untuk melakukan penelitian lebih lanjut, sehingga dari hasil penelitian ini dapat memberikan gambaran dan perspektif yang lebih jelas tentang keberadaan Program Inovasi Kelurahan dalam merealisasikan program, yang menunjukan adanya partisipasi, swadaya serta keberdayaan masyarakat yang signifikan. 
Dasar Hukum Program Inovasi Kelurahan di Kota Pontianak ini adalah Surat Keputusan Walikota Pontianak No. 301 Tahun 2012 tentang Petunjuk Operasional Program Inovasi Kelurahan. Program ini bertujuan untuk meningkatkan peran serta masyarakat dalam pembangunan sehingga persentase partisipasi swadaya masyarakat dalam kegiatan pembangunan kecamatan dan kelurahan. Hal ini sesuai yang dikatakan Walikota Pontianak pada Tanggal 24 April 2012 bahwa 'Pencanangan inovasi unggulan ini mendorong agar tiap-tiap kelurahan yang ada di Kota Pontianak untuk membuat sesuatu yang bernilai dan berharga, sehingga menjadi produk unggulan di setiap kelurahan'.

Penelitian ini bertujuan untuk menganalisa sejauh mana efekfitas Program Inovasi Keluarahan dari aspek ketepatan program, ketepatan implementor, ketepatan sasaran dan ketepatan lingkungan. Untuk itu masalah yang diteliti dirumuskan sebagai berikut: "Bagaimana Efektivitas Implementasi Program Inovasi Kelurahan di Kota Pontianak"

\section{Review Literatur}

Berbicara tentang program, pada umumnya yang dimaksudkan adalah suatu lingkup kegiatan Pemerintah yang relatif khusus dan cukup jelas batas-batasnya. Program mencakup serangkaian kegiatan yang menyangkut pengesahan atau legitimasi, pengorganisasian dan pengerahan atau penyediaan sumber-sumber daya yang diperlukan (Wahab, 2008). Program lebih bersifat operasional sehingga lebih mudah dapat dipahami dan dilaksanakan oleh pelaksana. Program tidak hanya berisi tentang kejelasan tujuan/sasaran yang ingin dicapai pemerintah, melainkan juga menggambarkan alokasi sumber daya yang diperlukan, kejelasan metode dan prosedur kerja yang harus ditempuh dan kejelasan standar yang harus diikuti. Sedangkan kebijakan dipakai untuk menunjukkan adanya pernyataan-pernyataan kehendak (keinginan) pemerintah mengenai tujuantujuan umum dari kegiatan-kegiatan yang dilakukan dalam suatu bidang tertentu, atau mengenai keadaan umum yang diharapkan dapat dicapai pada kurun waktu tertentu.

Berdasarkan pernyataan di atas menunjukkan bahwa program dan kebijakan berbeda tetapi mempunyai makna yang sama, yaitu sebagai suatu bentuk upaya pemerintah dalam memecahkan masalah yang dihadapi dengan menggunakan cara tertentu. Oleh karena itu, pada hakekatnya implementasi kebijakan adalah implementasi program (Tachjan, 2006).

Program Inovasi Kelurahan merupakan bagian dari usaha Pemerintah Kota Pontianak untuk membangun kapasitas dan memnerdayakan kelurahan sebagai ujung tombak pelayanan kepada masyarakat melalui kolaborasi, koordinasi dan konsultasi yang intensif dengan Satuan Kerja Perangkat Daerah tertentu sebagai partner kerjanya. Seperti yang dikemukakan oleh Nugroho (2009), bahwa untuk mengimplementasikan kebijakan publik, ada dua pilihan langkah yaitu: langsung mengimplementasikan dalam bentuk program atau melalui formulasi kebijakan derivate atau turunan dari kebijakan tersebut. 
Implementasi kebijakan pada hakekatnya tidak hanya terbatas pada tindakantindakan atau perilaku badan-badan administrasi atau unit birokrasi yang bertanggung jawab untuk melaksanakan program dan menimbulkan kepatuhan dari kelompok sasaran. Namun demikian, dalam implementasi kebijakan juga harus memperhatikan jaringan kekuatan politik, ekonomi dan sosial yang berpangaruh pada perilaku semua pihak yang terlibat dan pada akhirnya akan membawa dampak yang diharapkan bagi masyarakat maupun yang tidak diharapkan. Kekuatan-kekuatan politik, ekonomi, sosial dan budaya akan mempengaruhi aktor-aktor pelaksana dalam menjaga keefektifan implementasi. Faktor-faktor tersebut dinamakan sebagai lingkungan kebijakan (policy environment), yang juga sangat berpengaruh terhadap implementasi kebijakan publik.

Partisipasi masyarakat sangat penting dalam setiap implementasi kebijakan publik yang mengedepankan aspirasi dan kepentingan masyarakat. Jika partisipasi masyarakat tinggi maka kebijakan publik akan terlaksana dengan lancar dan baik. Dengan demikian peran aktif civil society sangat dibutuhkan sebagai saluran partisipasi untuk mendesakkan (pressure) kepentingan masyarakat. Civil society merupakan kumpulan institusi atau organisasi di luar pemerintah dan sektor swasta. Partisipasi aktif civil society tersebut akan menentukan keberlanjutan dari sebuah kebijakan publik.

Keberhasilan implementasi kebijakan publik dapat diukur dari sejauh mana efektivitas implementasinya. Efektivitas yang berasal dari kata efektif mengandung pengertian tercapainya tujuan yang telah ditetapkan. Efektivitas selalu terkait dengan hubungan antara hasil yang diharapkan dengan hasil yang telah dicapai. Kebijakan dikatakan efektif apabila output yang dihasilkan dapat memenuhi tujuan yang diharapkan. Efektivitas juga diartikan sebagai kemampuan untuk memilih tujuan yang tepat atau peralatan yang tepat untuk pencapaian tujuan yang telah ditetapkan (Handoko, 1995).

Ada 4 indikator untuk mengukur efektivitas implementasi kebijakan publik, seperti yang dikemukakan oleh Riant Nugroho (2004). Pertama adalah apakah kebijakannya sendiri sudah tepat. Ketepatan kebijakan ini dinilai dari sejauh mana kebijakan yang ada telah bermuatan hal hal yang memang memecahkan masalah yang hendak dipecahkan. Sisi kedua dari kebijakan adalah apakah kebijakan tersebut sudah dirumuskan sesuai dengan karakter masalah yang hendak dipecahkan. Sisi ketiga adalah, apakah kebijakan dibuat oleh lembaga yang mempunyai kewenangan yang sesuai dengan karakter kebijakannya.

Tepat yang kedua adalah "tepat pelaksananya". Aktor implementasi kebijakan tidaklah hanya pemerintah. Ada tiga lembaga yang dapat menjadi pelaksana, yaitu pemerintah, kerjasama antara pemerintah/swasta atau implementasi kebijakan yang diswastakan. Tepat yang ketiga adalah "tepat target", yang berkenaan dengan: (1) Apakah target yang diintervensi sesuai dengan yang direncanakan, apakah tidak ada tumpang tindih dengan intervensi yang lain atau tidak bertentangan dengan intervensi 
kebijakan lain. (2) Apakah targetnya dalam kondisi siap diintervensi atau tidak. Tepat keempat adalah "tepat lingkungan", ada dua lingkungan yang paling menentukan yaitu lingkungan kebijakan dan lingkungan eksternal kebijakan.

Keempat tepat tersebut masih perlu didukung oleh dukungan politik, dukungan strategic dan dukungan teknis. Dalam penelitian bertujuan untuk menganalisa efektivitas implementasi Program Inovasi Kelurahan yang ada di Kota Pontianak dari keempat indikator tesebut diatas. Penelitian ini berupaya memperluas pengembangan konsep implementasi program inovasi dengan memberikan penekanan-penekanan sebagai berikut:

1. Penelitian akan difokuskan pada efektivitas implementasi program melalui empat tepat: tepat kebijakannya, tepat pelaksananya, tepat target dan tepat lingkungannya.

2. Penelitian ini lebih memusatkan pada partisipasi masyarakat lokal pada setiap tahapan implementasi, mulai dari perencanaan, pelaksanaan, pemanfaatan sampai dengan tahap pemeliharaan hasil-hasil program.

3. Penelitian ini lebih menekankan kepada capacity bouplding yang mengacu pada kapasitas individual, kapasitas organisasional dan kapasitas masyarakat.

\section{Metode Penelitian}

Penelitian ini menggunakan pendekatan kualitatif dengan jenis penelitian deskriptif, yaitu dengan mendeskripsikan fenomena-fenomena tentang Efektivitas
Implementasi Program Inovasi Kelurahan di Kota Pontianak. Sumber data dalam penelitian ini adalah masyarakat Kota Pontianak yang telah menjadi target group dalam program ini, yaitu sekelompok masyarakat yang terorganisir dalam KSM (Kelompok Swadaya Masyarkat) maupun Kepala Keluarga sebagai sasaran individu. Sumber data yang lain adalah implementor program yang berasal dari pihak pemerintah (aparat kelurahan, aparat kecamatan, SKPD Pembina di Pemerintah Kota Pontianak).

Teknik pengumpulan data yang digunakan dalam penelitian ini adalah observasi, wawancara dan dokumentasi. Dengan ketiga teknik tersebut dapat diperoleh data tentang efektifitas implementasi Program Inovasi kelurahan di Kota Pontianak dan faktor-faktor yang menyebabkannya. Data yang dikumpulkan adalah tentang partisipasi dan efektifitas masyarakat dalam perencanaan, pelaksanaan dan pengawasan program dalam upaya pemberdayaan masyarakat Kota Pontianak. Sedangkan data dari implementor program adalah tentang langkah-langkah yang dilakukan aparat pelaksana dalam proses implementasi program, seperti pembentukan LPM/LKM sebagai organisasi pelaksana program di setiap kecamatan, jenis-jenis kegiatan, sumber daya anggarannya serta bagaimana koordinasi yang dilakukan diantara aparat pelaksananya.

Lokasi penelitiannya di Kota Pontianak yang meliputi 6 kecamatan yang terdiri dari 29 kelurahan. Penelitian ini lebih difokuskan pada implementasi tahun anggaran 2014. Implementor program ini terdiri dari tiga komponen yang terdiri dari 
pemerintah, masyarakat dan swasta. Penelitian ini rencananya dilaksanakan dalam kurun waktu 8 bulan, terhitung mulai dari persiapan sampai dengan pengiriman laporan akhir penelitian. Teknik analisa datanya menggunakan analisa data kualitatif, yaitu dengan mengeksplor dan menganalisis sejauh mana efektivitas implementasi Program Inovasi Kelurahan di Kota Pontianak. Untuk itu ada teknik triangulasi dalam penganalisaan data.

\section{Hasil dan Pembahasan}

Program Inovasi Kelurahan merupakan penjabaran lebih lanjut dan nyata dari program kewilayahan yang telah ditetapkan di dalam Perda No 5 Tahun 2009 tentang Rencana Pembangunan Jangka Menengah (RPJM) Kota Pontianak 2010 - 2014. Program ini bertujuan untuk menyeimbangkan tingkat pertumbuhan dan perkembangan antar wilayah di lingkungan Kota Pontianak dengan didasarkan atas potensi dan kekhasan yang dimiliki masing-masing wilayah.

Program Inovasi Kelurahan (PIK) adalah bagian dari usaha Pemerintah Kota Pontianak untuk membengun kapasitas dan memberdayakan kelurahan sebagai ujung tombak pelayanan kepada masyarakat melalui kolaborasi, koordinasi dan konsultasi yang intensif dengan Satuan Kerja Perangkat Daerah tertentu sebagai partner kerjanya.

Kelurahan sebagai garda terdepan dalam memberikan layanan kepada masyarakat menghadapi berbagai tantangan dan kendala dalam menjalankan tugas dan fungsinya di bawah koordinasi kecamatan.
Di sisi lain berbagai agenda pembangunan dilaksanakan oleh instansi teknis sebagai bagian dari pelaksanaan tugas dan fungsinya seringkali memerlukan dukungan kelurahan secara penuh. Kondisi ini memerlukan jalinan koodinasi dan kerja sama yang baik untuk memastikan seluruh agenda pembangunan terselenggara dengan baik.

Secara umum Program Inovasi Kelurahan bertujuan untuk terwujudnya jalinan kerja sama yang intens tanpa memandang garis kewenangan dan birokrasi sebagai hambatan dalam mengorganisir dan memobilisasi sumber daya yang ada di lingkungannya guna meningkatkan kapasitas dan memberdayakan kelurahan. Secara khusus tujuannya adalah sebagai berikut :

1. Mendorong terciptanya keunikan dari masing-masing kelurahan berbasis potensi yang dimilikinya dan didukung dengan kelebihan teknis yang dipunyai SKPD.

2. Mengembangkan inovasi pelaksanaan manajemen pemerintah dalam kaitannya dengan menenbus batasan birokrasi yang ada.

3. Meningkatkan kapasitas kelurahan dalam memfasilitasi pembangunan kelurahan yang berkelanjutan.

Prinsip Program Inovasi Kelurahan adalah suatu nilai dasar yang selalu menjadi landasan atau acuan dalam setiap tahapan pelaksanaan rangkaian kegiatan yang mendorong terjadinya tujuan sebagaimana telah disebutkan di atas. Prinsip-prinsip (dalam Petunjuk Operasional) tersebuat, adalah sebagai berikut: 


\section{Kesetaraan}

Bahwa di dalam pelaksanaan kegiatan masing-masing memiliki peran yang sama penting yang saling mendukung dalam setiap tahapan kegiatan yang dilalui mulai dari perencanaan, pelaksanaan dan monitoring serta evaluasi termasuk menerima manfaat dan menikmati hasilnya.

\section{Transparansi}

Bahwa masing-masing pelaku memahami perannya dalam kegiatan yang diputuskan bersama-sama serta memiliki kebebasan dalam melakukan pengendalian secara madiri sesuai dengan porsi masing-masing dalam kegiatan.

\section{Partisipasi}

Bahwa diperlukan pelibatan peran serta masyarakat dalam kegiatan yang didesain, mulai dari proses perencanaan, pelaksanaan, pengawasan serta pelestarian kegiatan dengan memberikan sumbangsih tenaga, pikiran ataupun dana maupun barang.

\section{Akuntabilitas}

Bahwa setiap pengelolaan kegiatan PIK harus dapat dipertanggungjawabkan baik kepada masyarakat maupun kepada semua pihak yang berwenang sesuai dengan peratuan dan ketentuan yang berlaku atau yang telah disepakati bersama.

\section{Keberlanjutan}

Bahwa dalam setiap tahapan kegiatan yang dilakukan mulai dari perencanaan, pelaksanaan, monitoring dan evaluasi, hendaknya mempertimbangkan aspek keberlangsungannya sehingga bukan hanya merupakan hal yang berlaku sesaat belaka, aka tetapi bersifat lestari dan dapat dinikmati dalam waktu lama.

Berdasarkan prinsip-prinsip dasar pelaksanaan Program Inovasi Kelurahan ini maka yang menjadi sasaran program ini adalah seluruh wilayah kelurahan yang ada di enam kecamatan di Kota Pontianak. Kelompok sasaran yang terlibat dalam pelaksanaan Program Inovasi Kelurahan ini adalah :

1. Institusi Kelurahan

2. Satuan Kerja Perangkat Daerah di Lingkungan Pemerintah Kota Pontianak

3. Kelembagaan masyarakat di Kota Pontianak

Berdasarkan kelompok sasaran (target group) yang berupa lembaga atau organisasi, maka pendanaan untuk pelaksanaan program ini bersumber dari:

1. APBD Kota Pontianak dalam bentuk kegiatan Inovasi Kelurahan di DPA Kelurahan dan kegiatan di SKPD

2. Swadaya masyarakat

3. Partisipasi dunia usaha atau pihak-pihak lain yang tidak mengikat.

Implementasi Program Inovasi Kelurahan di Kota Pontianak merupakan bagian dari usaha Pemerintah Kota Pontianak untuk membangun kapasitas dan memberdayakan kelurahan sebagai ujung tombak pelayanan kepada masyarakat. Program ini berusaha untuk mendorong terciptanya keunikan dari masing-masing kelurahan yang berbasis potensi yang dimilikinyadan mengembangkan inovasi manajemen pemerintahan serta meningkatkan kapasitas kelurahan dalam memfasilitasi pembangunan kelurahan 
yang berkelanjutan. Untuk mencapai tujuan tersebut sangat diperlukan adanya partisipasi dan komitmen dari pihak kelurahan, masyarakatnya dan SKPD yang sebagai partner kerjanya.

Berdasarkan hasil penelitian dan analisa data, maka ada beberapa kesimpulan yang dapat dikemukakan dalam penelitian ini, antara lain :

1. Program Inovasi Kelurahan merupakan salah satu usaha Pemerintah Kota Pontianak untuk membangun kapasitas dan memberdayakan kelurahan sebagai ujung tombak pelayanan kepada masyarakatmelalui kolaborasi, koordinasi dan konsultasi yang intensif dengan Satuan Kerja Perangkat Daerah tertentu sebagai partner kerjanya.

2. Efektifitas implementasi Program Inovasi Kelurahan di Kota Pontianak dapat dinilai dari empat 'tepat', yaitu: tepat kebijakannya, tepat pelaksananya, tepat target atau sasarannya dan tepat lingkungannya. Selain itu perlu didukung oleh tiga jenis dukungan, yaitu: dukungan politik, dukungan strategik dan dukungan teknis.

3. Kegiatan-kegiatan yang ada dalam Program Inovasi Kelurahan di Kota Pontianak dinilai sudah efektif, karena sebagian besar kegiatan telah memobilisasi sumber daya yang ada di lingkungannya guna meningkatkan kapasitas dan memberdayakan kelurahan.

4. Implementor atau pelaksana Program Inovasi Kelurahan di masing masing kelurahan telah sesuai antara tema kegiatannya dengan Satuan Kerja Perangkat daerah (SKPD) selaku
Pembina kegiatan tersebut.Sedangkan kelompok sasaran yang terlibat dalam implementasi PIK adalah : institusi kelurahan, SKPD di lingkungan Pemerintah Kota Pontianak dan kelembagaan masyarakat di Kota Pontianak.

5. Kegiatan-kegiatan yang ada di masingmasing kelurahan dalam Program Inovasi Kelurahan di Kota Pontianak dinilai sudah sesuai dengan lingkungannya, karena kegiatannya disesuaikan dengan kondisi lingkungannya dan telah memberikan manfaat yang luas kepada masyarakat

Berdasarkan beberapa kesimpulan tentang efektifitas implementasi Program Inovasi Kelurahan di Kota Pontianak, dapat disarankan sebagai berikut:

1. Diharapkan Program Inovasi Kelurahan ini dapat meningkatkan kapasitas aparatur kelurahan dan pemberdayaan masyarakat yang disesuaikan dengan potensi yang dimiliki kelurahan masingmasing di Kota Pontianak.

2. Untuk lebih meningkatkan efektifitas implementasi Program Inovasi Kelurahan, diperlukan adanya kerja sama yang baik antara masyarakat, SKPD Pembina dan organisasi sosial yang ada di kelurahan dalam melaksanakan program ini

3. Partisipasi dunia usaha atau pihak-pihak lain sangat diharapkan dalam pengelolaan dana implementasi Program Inovasi Kelurahan di Kota Pontianak, sehingga program ini akan memberikan manfaat yang sebesarbesarnya kepada masyarakat. 
4. Disarankan Program Inovasi Kelurahan di Kota Pontianak berkesinambungan dari tahun ke tahun, karena program ini dapat mendorong kemandirian masyarakat dan institusi kelurahan untuk memperbaiki lingkungannya.

\section{Daftar Pustaka}

Abdul Wahab, Solichin. 2002. Analisis Kebijaksanaan, Dari Formulasi Ke Implementasi Kebijaksanaan Negara. Jakarta : Bumi Aksara. 2008. Pengantar Analisis Kebijakan Publik. Malang: UMM Press.

Agustino, Leo. 2006. Politik dan Kebijakan Publik. Bandung : AIPI Bandung dan Puslit KP2W Lemlit Unpad.

2006. Dasar-Dasar

Kebijakan Publik. Bandung : CV Alfabeta.

Indiahono, Dwiyanto. 2009. Kebijakan Publik Berbasis Dynamic Policy Analisys. Yogyakarta : Gava Media.

Islami, Irfan. 2000. Prinsip-Prinsip Perumusan Kebijaksanaan Negara. Jakarta : PT. Bumi Aksara.

Jones, O. Charles. 1996. Nashir Budiman (Editor). Public Policy. Jakarta: PT. Raja Grafindo Persada.

Kartasasmita, Ginanjar. 1997. Administrasi Pembangunan. Jakarta: LP3ES.

Keban, Yeremias T. 2004. Enam Dimensi Strategis Administrasi Publik, Konsep, Teori dan Isu. Yogyakarta: Gava Media.
Koentjaraningrat. 1980. Kebudayaan Mentalitet dan Pembangunan. Jakarta : Gramedia.

Kay, Adrian. 2006. The Dynamic of Public Policy. USA : Edward Elgar Publishing.

Mustopadidjaja. 2002. Manajemen Proses Kebijakan Publik. Jakarta : Lembaga Administrasi Negara.

Nawawi, Ismail. 2009. Public Policy, Analisis,Strategi Advokasi Teori dan Praktek. Surabaya : PMN.

Nugroho, D, Riant. 2002. Kebijakan Publik untuk Negara-Negara Berkembang. Jakarta : PT Elex Media Komputindo.

2004. Kebijakan

Publik, Formulasi, Implementasi dan Evaluasi. Jakarta : PT Gramedia.

Pranarka dan Ony S. Prijono. 1996. Pemberdayaan Konsep, Kebijakan dan Implementasi. Jakarta : CSIS.

Putra, Fadillah. 2001. Paradigma Kritis dalam Studi Kebijakan Publik. Surabaya : Pustaka Pelajar.

Sabatier, Paul A and Hank C. JenkinsSmith. 1993. Policy Change and Learning : An Advocacy Coalition Approach. Westview Press : Boulder, Co.

Silalahi, Ulber. 2009. Metode Penelitian Sosial. Jakarta : Rafika Aditama.

Suharto, Edi. 2008. Analisis Kebijakan Publik. Bandung : Alfabeta.

2005. Membangun Masyarakat Memberdayakan Rakyat. Bandung : Refika Aditama. 
Tachjan. 2006. Implementasi Kebijakan Publik. Bandung : AIPI dan Puslit KP2W Lembaga Penelitian Unpad.
Widodo, Joko. 2007. Analisis Kebijakan Publik, Konsep dan Aplikasi Analisis Proses Kebijakan Publik. Malang : Bayumedia Publishing. 